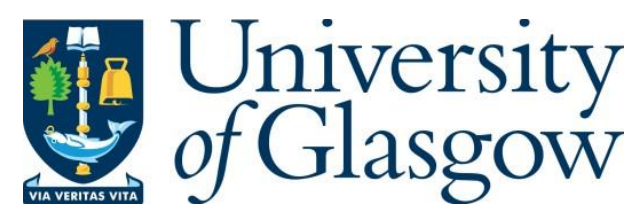

Gallhofer, S. (2018) Going beyond Western dualism: towards corporate nature responsibility reporting. Accounting, Auditing and Accountability Journal, (doi:10.1108/AAAJ-12-2015-2358).

There may be differences between this version and the published version. You are advised to consult the publisher's version if you wish to cite from it.

http://eprints.gla.ac.uk/147520/

Deposited on: 7 September 2017

Enlighten - Research publications by members of the University of Glasgow http://eprints.gla.ac.uk 


\section{GOING BEYOND WESTERN DUALISM:}

TOWARDS CORPORATE NATURE RESPONSIBILITY REPORTING (CNRR)

Sonja Gallhofer

Adam Smith Business School

University of Glasgow

Accounting, Auditing and Accountability Journal

(forthcoming) 


\title{
GOING BEYOND WESTERN DUALISM: TOWARDS CORPORATE NATURE RESPONSIBILITY REPORTING (CNRR)
}

\begin{abstract}
Purpose - This paper outlines an ecofeminist lens for the analysis of accounting, which is applied to: first, the critique of corporate social responsibility reporting (CSRR); second, the elaboration of elements of a framework for a new accounting corporate nature responsibility reporting (CNRR) - as a response to the critique of CSRR; and, third, the consideration of elements of an enabling and emancipatory praxis in the context of CNRR, including a sketch of a research agenda.
\end{abstract}

Design/Methodology/Approach - a critical application of aspects of the ecofeminist critique of Western dualism and its emphasis on wholeness, interconnectedness and relatedness, including its particular delineation of nature, to the critique and design of accounting.

Findings - Insights from the application of an ecofeminist lens to the critique of CSRR raise questions about the suitability of the western notion of corporate social responsibility (CSR) and its associated accounting currently in use. In order to go beyond critique, the paper introduces the notions of corporate nature responsibility $(C N R)$ and corporate nature responsibility reporting $(C N R R)$ and offers an outline of key elements of CNRR and an emancipatory praxis in the context of CNRR, including a sketch of a research agenda. My elaborations suggest that in order to overcome the limitations of CSR and CSRR a corporation ought to be concerned about its broader and holistic corporate nature responsibility $(C N R)$. And, it should provide a CNR report, as part of a holistic corporate nature responsibility reporting (CNRR) concerned with the performance of the company in the context of CNR.

Originality/Value - Ecofeminism's critique of western dichotomous thinking has been given little consideration in prior studies of accounting. The paper thus draws attention to the relevance of an ecofeminist theoretical lens for the critique and design of accounting by focusing on CSRR. The paper introduces the concepts of corporate nature responsibility (CNR) and corporate nature responsibility reporting (CNRR) to address the limitations of CSRR as currently practiced.

Type of Paper - Theoretical and conceptual

Keywords - corporate social responsibility; corporate social responsibility reporting; corporate nature responsibility; corporate nature responsibility reporting; ecofeminism; Western dichotomous thinking 


\title{
GOING BEYOND WESTERN DUALISM:
}

\section{TOWARDS CORPORATE NATURE RESPONSIBILITY REPORTING (CNRR)}

\begin{abstract}
...western culture has treated the human/nature relation as a dualism and...this explains many of the problematic features of the west's treatment of nature which underlie the environmental crisis, especially the western construction of human identity as 'outside' of nature.
\end{abstract}

(Plumwood, 1993, p. 2)

\section{INTRODUCTION}

The $21^{\text {st }}$ century witnesses an ecological crisis, which policy makers and governments can no longer ignore (Breyer et al, 2016; Cooper and Senkl, 2016). Global and regional attempts at the policy level thus evidence concerns to introduce changes, which will steer us away from ecological catastrophe. However limited these attempts may be, they are an indication of an emerging global rethinking in terms of how we - humans - interrelate with the non-human world (commonly referred to as the environment or nature). In this broader context the impact of corporations and business organisations on the environment has become a major focus of concern (Radford Ruether, 2005). Corporations and business organisations are seen as both, major contributors to the ecological crisis as well as important actors in attempts to stop ecological damage and to reverse it (Maunders and Burritt, 1991; Welford, 1997; Gray and Bebbington, 2000). In the context of debates about the social responsibility of corporations, a corporation's responsibility to the environment and thus the need to operate in a sustainable way are emphasised. Since especially the late 1990s corporations and business organisations have responded to such debates by voluntarily increasing the disclosure of information about their environmental impact through corporate social responsibility reporting (CSRR) (Owen, 1992a, b; Owen and O'Dwyer, 2008). ${ }^{1}$ The literature on CSRR is critical of these attempts and has pointed to the PR nature and legitimation function of CSRR and to managerial capture (see, for example, Gallhofer and Haslam, 1997; Owen et al, 2000; Gray and Milne, 2002; Milne and Patten, 2002; O'Dwyer, 2003; Spence, 2007; Archel et al, 2009; Aras and Crowther, 2009; Burritt and Schaltegger, 2010). Although this literature has provided many relevant insights there is a need to go beyond current critique and suggestions for change to drive the debate forward. This is especially the case because much of the research on CSRR has adopted what Andrew (2000, p. 203) referred to as 'reformist approach[es] to environmental issues', which lack critical examination of 'the broader framework and assumptions' of the cultural practice of accounting. For me, a particularly problematic issue in the context of CSRR research to date is its lack of critical engagement with the Western construction of the interrelationship between humans and nature in critiques of CSRR as currently practiced as well as in proposals for design and praxis more generally. This is somewhat surprising as a critique of Western dualism's impact on accounting as currently practiced and prescribed by various national and global regulators is well rehearsed in the literature. I am therefore interested in revisiting how the Western construction of the human-nature interrelationship, which reflects the dualism inherent in Western thinking, shapes representations of nature in CSRR. My aim is to gain further

\footnotetext{
${ }^{1}$ I am using CSRR here as a generic term for voluntary disclosure, which reflects a concern about corporate social responsibility.
} 
insights for the critique of CSRR as currently practiced as well as the design of new accountings and the development of a research agenda. Through an ecofeminist lens I address the following research questions: What insights can be gained from applying an ecofeminist framework to the critique of CSRR? What new possibilities emerge from such a critique for the design of accountings that go beyond the limitations of current CSRR practice? What are the implications of the new envisaged accountings for an enabling and emancipatory praxis, including the sketching of a research agenda? The reminder of the paper explores these questions and is structured as follows: elaboration of an ecofeminist theoretical lens for the analysis and design of accountings; summary overview of the insights gained from mobilising the ecofeminist lens in the critique of CSRR; exploration of the implications of an ecofeminist lens for the design of new accountings; outline of elements of an emancipatory praxis in the context of CSRR, including a sketch of an agenda for research; and, concluding comments.

\section{TOWARDS AN ECOFEMNIST LENS FOR THE CRITIQUE OF CSRR, AND THE DESIGN OF NEW ACCOUNTINGS FOR NATURE ${ }^{2}$}

Research in accounting that mobilises feminist perspectives for a critique of accounting as currently practiced und for an exploration of possibilities for new accountings is rare (Haynes, 2016). And, it is even rarer in the case of work, which focuses on feminist critiques of the Western dualism that shapes accounting as currently practiced. ${ }^{3}$ And, to the best of my knowledge there is no published paper that has developed a critique of Western accounting and the Western dualism it reflects from an ecofeminist perspective. ${ }^{4}$ A review of the accounting literature identified three papers published in the 1990s that are especially relevant for my focus - Western dualism in accounting as currently practiced: namely, Cooper (1992) ${ }^{5}$, Hines (1992) and Broadbent (1998). Critically engaging with these papers has helped me to better clarify what an ecofeminist lens can add to our understanding of accounting in general and CSRR in particular and encouraged me to develop a vision of what for me constitutes a better $^{6}$ accounting for nature. Below I offer a critical appreciation of these three papers, which highlights key contributions as well as key limitations of their analyses. I then make out a case for ecofeminism as a theoretical lens that can build upon but in important ways also goes beyond these three papers. I end this section with a sketch of the elements of the ecofeminist lens that frames my critique of CSRR as currently practiced and my suggestions for the design of a better accounting for nature.

\footnotetext{
${ }^{2}$ Nature in the construct accounting for nature reflects the holistic ecofeminist delineation of nature, which emphasises that humans are part of nature.

3 Cooper and Senkl (2016, p. 495) recently observed that 'there is a scant literature which considers social and environmental accounting from a feminist perspective'.

${ }^{4}$ At the time of writing there was only one conference paper available on the web that focused on environmental disclosure and accountability from an ecofeminist perspective (Buhr and Reiter, 2000).

${ }^{5}$ Cooper and Senkl (2016) adopts the same feminist theoretical perspective as developed and outlined in detail in Cooper (1992) but only provides a brief summary of this approach and is thus excluded from my detailed discussions here. I, however, refer to Cooper and Senkl (2016) in the text where appropriate.

${ }^{6}$ I am using the term "better" to denote an accounting that goes beyond at least some of the limitations of current practice, which have been identified through critical analyses.
} 


\section{Critiques of Western dualism in the accounting literature inspired by radical French feminism and ancient Eastern philosophy: the contributions of Cooper (1992), Hines (1992) and Broadbent (1998)}

Cooper (1992), Hines (1992) and Broadbent (1998) identify key shortcomings of accounting as currently practiced and comment on the possibility of envisioning a better accounting. They make reference to the interrelationship between accounting and nature, although Hines (1992) and Broadbent (1998) only tangentially, whereas it is a key focus in Cooper (1992). The theoretical issue central to the analyses in these papers is the dualism evident in Western thought. This dualism is understood to be a major factor in the shaping of Western accounting as currently practiced and therefore key to an understanding of its shortcomings. Despite these commonalities in focus there are important differences in the explanations and suggestions for change these authors offer, reflecting the different theoretical lenses adopted: feminist lenses in Cooper (1992) and Broadbent (1998); an Eastern philosophical lens in Hines (1992).

For Hines (1992), Western dualism is the result of an imbalance between the Universal feminine and the Universal Masculine, the Yin and Yang as per ancient Chinese philosophy. Yin and Yang, although polar opposites, are normally in harmony and a unity. The imbalance that has occurred has led to the repression of the Universal Feminine and 'ways of thinking, feeling, being and acting that are associated with the Universal Feminine' by the Universal Masculine thus creating the dualism evident in Western thought (ibid., p. 314). Accounting as currently practiced is understood to reflect the values of the Universal Masculine thus being an accomplice in the suppression of the Universal Feminine and in reproducing and sustaining Western dualism. Regarding nature, seen as the embodiment of the Universal Feminine, this suppression encouraged the view that nature can be controlled and exploited by man, a view still dominant in the West today. For Broadbent (1998, p. 269), building upon Hines (1992), it is the lack of balance in accounting as currently practiced, which 'privileges the harder masculine values at the expense of softer, feminine ones'. This is especially evident in the values that underpin accounting logic. For Cooper (1992), the dualism in Western thinking reflects the dominant phallogocentric symbolic order and thus patriarchal power, which sustains the oppression of women and shapes social practices, including accounting (see also Cooper and Senkl, 2016, pp. 500-501). The above interpretations have significantly contributed to our understanding of accounting but they also have important limitations in terms of their critique of accounting as currently practiced and the proposals for change they offer. For example, Hines (1992) and Cooper (1992) in focusing on universal categories fail to adequately address differences within these universals such as differences in relation to class, ethnicity, race, age, sexual orientation and faith systems (Gallhofer, 1992), which are significant in shaping the way repressions are experienced and emancipatory strategies envisioned. Without consideration of how accounting as currently practiced affects different groups of people differently analysis will be partial and fail to offer a holistic view of the way an accounting reflecting masculine values affects society and the environment. A further limitation of the above analyses is their lack of appreciation of the embedded character of accounting, for example, how accounting affects people's lives and the environment depending on geographical location and time. And, there is a lack of consideration of imperialism and colonialism and their impact on accounting, people and the environment. 
For me, Cooper (1992), Hines (1992) and Broadbent (1998) are particularly interesting because of their suggestions for praxis, which provide valuable insights into the limitations of the theories that have shaped their argumentation. For Hines (1992, p. 336) alternative accounting research has an important role in addressing the current imbalance between the Universal Masculine and the Universal Feminine. ${ }^{7}$ But interestingly, despite the importance attributed to alternative accounting research, Hines (1992, p. 337) does not offer any directions for future research or any other suggestions for a praxis implicating accounting: "There are no "conclusions" to this paper...much less hard directives for future research'. Cooper (1992, p. 25), who was interested in exploring if accountants can solve environmental issues concluded that accounting for the environment was problematic because of the "masculine" phallogocentric nature of accounting', which is goal-centred and profit-centred. The implications for praxis are similar to those suggested by Hines (1992), namely 'in the present symbolic order accountants should not attempt to account for the environment' (Cooper, 1992, p. 37) but stay in the margins until the masculine phallogocentric order has been changed. Interestingly, Broadbent (1998), also adopting the concept of the Universal Masculine and Feminine, takes a different stance in terms of the implications of her analysis for praxis. For her, the imbalance between the Universal Yin and Yang that currently shapes accounting should be addressed and attempts made to restore balance. This suggestion reflects the emancipatory intent of the feminist critical theoretical interpretations of Habermas, which inform the theoretical lens of Broadbent (1988). In contrast to Hines (1992) and Cooper (1992), Broadbent (1998) thus mobilises the Universal Feminine to engender change and offers a detailed agenda for a more enabling accounting. The key suggestion is that through the inclusion of broader values and subjectivity in the decision-making about financial issues the values of accounting logic can be countered. Although Broadbent (1998) is an important contribution it is limited by the lack of consideration of difference and the Westerncentrism in much of Habermas' theorising (Sevänen, 2004; Vieten, 2011).

Although the above papers are inspiring and provide many interesting insights they only tangentially address or and are silent about issues I am interested in exploring here, namely the role of Western dualism evident in the interrelationship between humans and nature and the 'cultural practice' of accounting (Andrew, 2000) and the implications of this for the critique of CSRR as currently practiced, the design of new accountings and the development of a research agenda.

For me the limitations I have identified in Cooper (1992), Hines (1992) and Broadbent (1998) are a reflection of the shortcomings of their theoretical lenses. These lenses, although having highlighted interesting issues, have been partial in terms of the insights they provided and thus constrained the envisioning of new accountings that would go beyond an accounting reflecting (universal) masculine values. For me, an appropriate theory to address the limitations I have identified above is ecofeminism. There are several reasons for why ecofeminism is a suitable theory for my purposes. Most importantly, ecofeminism offers a critique of how Western dualism shapes the interrelationship between humans and nature. On a general level, ecofeminism has much in common with

\footnotetext{
${ }^{7}$ Hines (1992) characterizes alternative research as an attempt to retrieve the lost Universal Feminine or Yin; having a concern for the subjective; illuminating the interdependence between the inner and outer, subject and object, observer and observed, mind and matter, and the illusionary nature of their presumed split.
} 
postmodern, deep green and radical feminist critiques of Western dualism. But because of its very particular way of seeing, ecofeminism also goes beyond these critiques in important ways (Buhr and Reiter, 2000). For example, it draws attention to patriarchal power, which, according to ecofeminists, sustains the oppression of both women and nature (Plumwood, 1993; Warren, 1994, 1997; Merchant, 2005). In highlighting the role of patriarchal power ecofeminism goes beyond the argumentation of deep ecology, which focuses upon anthropocentricism in its critique and thus fails to adequately address the role of androcentric power in the oppression of nature by humans (Kheel, 1991; Sessions, 1991; Slicer, 1995). The emphasis on patriarchal power in ecofeminist theorising also challenges social ecology by highlighting the gendered nature of oppression, which social ecology is silent about (Merchant, 2005). And, in drawing attention to the multiple forms of patriarchal oppression ecofeminists also challenge the universal concept of patriarchal power inherent in radical feminist theorising. What makes ecofeminism especially appropriate as a theoretical framework is its concern to theorise power relations at the personal as well as systemic level (Birkeland, 1993, p. 16) thus facilitating holistic analyses. As Birkeland (1993, pp. 31-32; cited in Buhr and Reiter, 2000, p. 4) has noted:

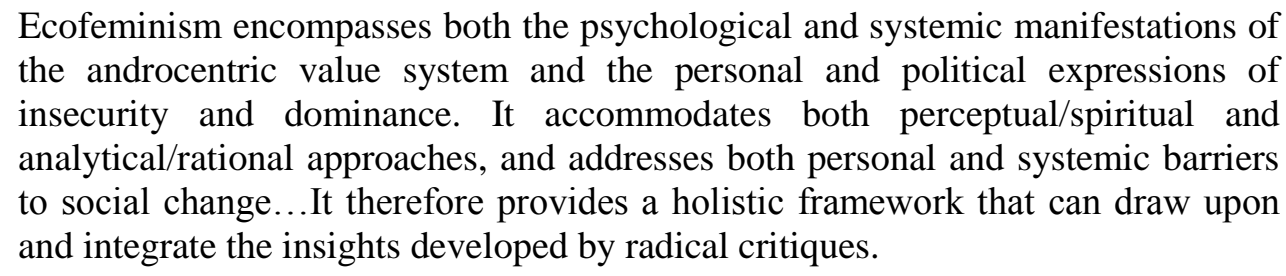

Given the important differences between ecofeminist theorising and other theoretical approaches and its holistic orientation it is therefore reasonable to assume that adopting an ecofeminist lens when critiquing the representation of nature in CSRR will provide additional insights. This applies to the critique of accounting as currently practiced as well as to attempts to design new accountings for "nature".

\section{Key elements of an ecofeminist critique}

In this section I provide an outline of some key characteristics of ecofeminist theorising, including a discussion of its critique of Western dualism as evident in the human-nature interrelationship and the shaping of human identity. I end my discussions with an outline of the emancipatory praxis suggested by ecofeminists. The issues I address below are relevant for the critique of CSRR as currently practiced and my attempt to design a new accounting for nature.

\section{Ecofeminism: a brief outline}

Before I begin my elaborations I want to highlight an important characteristic of ecofeminism: ecofeminism is not the domain of women and it is not anti-men. Mindful of the perception that ecofeminism is only for women, Greta Gaard and Patrick Murphy (1998, p. 1) made the following comment about their joint editorship of a book on ecofeminist literary criticism:

We were pleased that our collaboration would provide another example of men and women working together to build ecofeminism, thereby undermining the misconception that ecofeminism is the province of women alone. 
Ecofeminism is an umbrella term for theoretical positions that explore the interrelationship between women and humans in subordinate positions and the domination and exploitation of nature (Gaard, 1993; Merchant, 2005; Glazebrook, 2014; Irving and Helin, 2017). Of interest is the critique of dichotomies ${ }^{8}$, which explores how binary or dichotomous thinking has shaped and still shapes Western understandings and representations of the interrelation between humans and the non-human world (Plumwood, 1993; Warren, 1994; Nhanenge, 2011; Phillips, 2017) and related emancipatory praxis.

Ecofeminists have argued that it is patriarchal power, which engenders the domination and subordination of both, women and nature (Shiva, 1989; Warren, 1994; Nhangene, 2011; Wachholz, 2011; Glazebrook, 2014). Since its emergence in the 1970s ecofeminist theorizing shifted away from a focus on patriarchal domination as the key type of domination in the subordination of women and nature to an emphasis on a complex interrelated web of dominations - one element but not the only - being patriarchal domination.

Another and important emphasis in ecofeminist thought is a moving away from westerncentric and universal analysis and an embracing of non-Western thought about the interconnectedness of humans and non-humans (Warren, 1994). Ecofeminist analyses and theorising recognises the 'inextricable interconnectedness among all [emphasis in original] social systems of domination, for instance racism, classism, ageism, ethnocentrism, imperialism, colonialism, as well as sexism', which makes ecofeminism more inclusive and holistic than other forms of feminism (Warren, 1994, p. 2; Phillips, 2015). This inclusive character of ecofeminism is reflected in the emancipatory praxis it advocates. $^{9}$

\section{The ecofeminist critique of the "human/nature" binary}

The ecofeminist critique of the key dichotomy in Western thought that represents the interrelationship between humans and nature - namely, human/nature and its variants, such as, 'culture/nature, reason/nature, male/female, mind/body (nature), master/slave, reason/matter (physicality), reason/emotion (nature)...freedom/necessity... civilised/primitive (nature), production/reproduction (nature)' (Plumwood, 1993, p. 43) has provided important insights for an understanding of western human identity in relation to nature.

Ecofeminists have highlighted the interconnectedness of women and nature and their shared experience of patriarchal domination. Ecofeminists argue that in the human/nature dichotomy the "human" is seen as male (man) and "nature" as female (woman) (c.f. de Beauvoir, 2010). Plumwood (1993, p. 3) argued that it is the central and dominant role of reason, 'the protagonist-superhero of the Western psyche' and associated with man, that has shaped the way nature is seen in the West:

\footnotetext{
${ }^{8}$ In their critique ecofeminists have built upon the general feminist critique of dichotomies (Prokhovnik, 1999).

${ }^{9}$ It should be noted that ecofeminism has not been without its critics. A point of critique made of ecofeminism is a concern about essentialism evident in ecofeminist thought (Godfrey, 2005). As Wachholz (2011, p. 289) has pointed out, however, this only applies to one strand of ecofeminist theorising, namely essentialist ecofeminism.
} 
The concept of reason provides the unifying and defining contrast or the concept of nature, much as the concept of husband does for that of wife, as master for slave. Reason in the western tradition has been constructed as the privileged domain of the master, who has conceived nature as a wife or subordinate other encompassing and representing the sphere of materiality, subsistence and the feminine which the master has split off and constructed as beneath him. ${ }^{10}$

The dominant position of humans in relation to nature - now taken-for-granted in Western thought - solidified during the Enlightenment: thinking humans are seen as superior, a status that justifies their domination of "mindless" nature (Plumwood, 1993; see also Merchant, 2013). Nature became seen as a commodity, a resource in the quest for progress and development (Plumwood, 1993, 2002). It is only more recently that there is a wider recognition of the disastrous consequences of the way of acting as if humans and nature constituted two opposites in a relation of domination and subordination (Gaard, 2015).

It is important to note that the notion of human identity as the master of nature and thus disconnected from nature is still deeply embedded in Western thought. This way of thinking has become so firmly rooted in the Western psyche that it appears to subconsciously affect how people position themselves in relation to nature, namely as being different from and outside of nature. The following dialogue illustrates this point:

Me: "I was sitting on the grass near the pond in the philosopher's garden. The sun was shining; the trees were in full bloom and the birds sang with joy. The summer air was gentle and warm, filled with the scent of flowers and full of expectations. I could feel the wind playing with my hair as I watched the sunrays dancing on the water. Suddenly I felt that I was becoming part of nature."

My Japanese Friend: "But you are part of nature."

I had shared this story of my experience many times with Western friends and they all seemed to understand the experience I tried to describe. Only when I shared the same story with a Japanese friend I was challenged, as my story did not make sense from a Japanese perspective. I was astonished and disturbed by the response because it became clear to me that my experience had been based on an unconscious acceptance of the Western notion of the interrelationship between humans and nature. My experience also indicates that, as King (1989, p. 6) has argued, '[a]t the root of 'Western society exist[s]...a terrible confusion about our place in nature'.

\section{Beyond critique - towards an emancipatory praxis}

Following on from their critique of reason and anthropocentric and androcentric binaries ecofeminists have explored ways of developing an emancipatory praxis aimed at going beyond western dichotomous ways of relating to nature. Of particular interest is Val Plumwood's proposition of an emancipatory praxis in Feminism and the Mastery of Nature (1993): she ends her book by suggesting a praxis for change, which is aimed at 'changing the master story'. This suggestion is both simple and complex at the same time. It is simple, as it suggests that a different way of seeing the human-nature interrelationship

10 For Plumwood (1993, p. 5) a masculine presence 'is not a masculine identity pure and simple, but the multiple, complex cultural identity of the master formed in the context of class, race species and gender domination'. 
engenders change in human actions. It is complex, as changing dominant western ways of seeing implies going beyond dichotomies and moving from a thinking that focuses on "either/or" to one that focuses on "and". How can one begin to develop a praxis aimed at changing the master story? For Plumwood (1993, p. 5) this implies beginning to challenge Cartesian thought and its distinction 'between the conscious, mindful human sphere and the mindless, clockwork natural' sphere. Ecofeminists thus have explored the characteristics of a human-nature interrelationship, which would not be based on (male) reason and dichotomous (male) thinking (Nhanenge, 2011, p. 433). In this context, they have highlighted the importance of challenging the Western understanding of a "person" as an individual (Gebara, 1999) and introduced the notion of "selves...[as]..."selves-inrelation"” (Nhanenge, 2011, p. 439).

Further, ecofeminists have pointed to the importance of interrelatedness, interconnectedness, kinship, harmony and holism in the human-nature interrelationship (Plumwood, 1993; Gebara, 1999; Warren, 1994, 1997; Nhanenge, 2011). From such a perspective the human-nature interrelationship is non-dominant and devoid of dualism: humans are part of nature. Consequently, any concern about humans is also a concern about nature and how nature is treated affects humans in the same way. There are no clearcut boundaries between the elements that constitute nature but there is fluidity precisely because of the interconnectedness: everything is part of the whole and the whole is part of everything (Keller, 1989). If we adopt this way of seeing in relation to how we - humans interrelate with nature then the dichotomous relationship, and with it the legitimation for the domination and subordination of nature, vanishes. Humans (especially) in the West would begin to see themselves again as one with nature - a position still in different degrees evident in non-Western and indigenous cultures - and become aware of the responsibilities that come with such an identity position. Such a change in the way of seeing nature would contribute to the transformation of the master story that Plumwood (1993) advocated as a form of praxis. A truly emancipatory move!

It is important to briefly explore accounting's potential role in attempts to change the master story. We can gain interesting insights here from accounting researchers who have examined the enabling and emancipatory potential of accounting (for example, Tinker, 1985; Gallhofer and Haslam, 2003, 2017; Buhr, 2011; Kamla, 2015; Lombardi, 2016). For these researchers, accounting can and should play a part in processes aimed at achieving a transformation of the status quo that would enhance wellbeing. Accounting's potential to create visibilities that can engender emancipatory action is especially relevant here: accounting can create visibilities of how the dualism in Western thought shapes human actions and the negative impact of this. The awareness thus created can facilitate the critical reflection needed to encourage the challenging of dichotomous thinking and the development of different and holistic ways of thinking. I am aware that changing the way we think is a mammoth task, complex and often contradictory with an outcome that cannot be anticipated but at the same time I believe that we ought to be bold and embrace the task as we have nothing to loose but much to gain.

Having outlined the key elements of an ecofeminist lens I now turn to the challenge of applying this theoretical lens to a critical appreciation of current CSRR, the envisioning of a new accounting for nature and an emancipatory praxis in the context of an accounting for nature. To deal with the complexities involved in this task I adopt the Critical Systems Model (CSM) (Gallhofer and Haslam, 2003; 2008) to structure my elaborations. As suggested by the CSM, this involves the following stages: first, a critique of 
representations of nature in accounting as currently practiced; second, the envisioning of new designs of accounting for nature, which respond to and transcend the critique; and, third, a consideration of strategies in the context of an emancipatory praxis for the realisation of the new accountings envisioned. The latter step also includes the development of a research agenda.

\section{BEYOND BINARIES: APPLYING THE ECOFEMINIST LENS TO THE CRITIQUE OF CSRR AND THE DESIGN OF NEW ACCOUNTINGS FOR NATURE}

\section{Insights from ecofeminist theorising for a critique of the accounting - nature interrelationship}

From an ecofeminist perspective, key focuses of a critique of accounting as currently practiced are accounting representations of nature and the human-nature interrelationship that shapes these representations. An ecofeminist lens draws especially attention to the role of Western dualism. The concern about dualism's impact on accounting is not new and some insights of prior work are also relevant from an ecofeminist perspective, for example, Cooper's (1992, p. 25) insightful elaboration of the binary character of accounting, or, Hines's (1992, p. p. 328) characterisation of accounting as reflecting Yang (Universal Masculine) values. Ecofeminist theorizing draws attention to the power of humans to shape accounting representations of nature, including, financial and quantified representations, narratives, graphs and photographs: humans play an active role in deciding what is represented in CSRR, how it is represented and to whom.

It is of interest to consider the ecofeminist suggestion that it is patriarchal power that sustains the domination of both nature and women. This points to the relevance of the binary patriarchal power/women and nature for the critique of accounting as currently practiced. Although the feminist literature on accounting has provided valuable insights into how male values and patriarchal power have shaped accounting it has not considered the implications of the ecofeminist suggestion that patriarchal power sustains the oppression of women and nature for a critique of accounting as currently practiced. It is thus of interest to explore this in more detail.

One way of beginning such an exploration is to consider how patriarchal power might be challenged and overturned because understanding challenges to power draws attention to issues that need to be considered by those who wish to sustain their power and their ability to oppress others. In the case of the oppression of nature and women by the same source of power, an awareness of having the same oppressor can create solidarity and bring together those concerned about the oppression of women and those concerned about the oppression of nature. Patriarchal power therefore has to ensure that this joining of forces in solidarity is prevented. One possible strategy is to call upon accounting representations of nature and women. Accounting reflecting male values is well suited for this task: through "cutting up" and "compartmentalising" (Hines, 1992, p. 329) it does not allude to any interrelationship or interconnectedness between women and nature in its representations (i.e. the environment in CSRR). Reporting about women and reporting about nature are two distinct and independent categories with fixed and impermeable borders. 
The lack of appreciation of relatedness and interconnectedness in accounting representations of women and nature reflects male values, which prefer order, objectivity and clear boundaries to the subjectivity and messiness of relationships (Hines, 1992; Broadbent, 1998). This translates into accounting representations of women and nature, which denote a divide and rule that marginalises solidarity and delimits visions of an emancipatory praxis that would get its impetus from a recognition of joint suffering engendered by the same oppressor. It is thus reasonable to argue that accounting representations of nature and women help sustain the dominant order and power structure. ${ }^{11}$ Accounting's role in sustaining the status quo - i.e. the repression of women and nature by the same source of power - is further enhanced as accounting representations of women and nature are silent about difference: nature and women are represented as abstract universal categories devoid of subjectivity, feelings and the ability to form relationships. Throughout CSR reports, for example, reference is mainly made to the broad and undefined universal term "environment". Under the umbrella of "environment" issues relating to greenhouse gas emissions, climate change, water, seabed fauna, seafood, minerals, biodiversity, habitat (for example, BP, 2014; Rio Tinto, 2015; Shell, 2015; Ford, 2016) ${ }^{12}$ are discussed. The term environment in the context of CSRR potentially can mean almost anything that the reader wishes it to mean. As a consequence, the multiplicity and specificities of the other disappear in a black box and remain unrepresented.

Further, reflecting dichotomous thinking, the environment is portrayed as passive and without agency, something that exists and must be dealt with and acted upon by the company. BP (2014, back of front cover of the report), for example, reports that 'we are applying innovative technology to access gas locked in hot sandstone almost three miles below the earth's surface'.

In the case of nature, its representation in CSR reports makes it possible to see it as a mere commodity, ready for use (exploitation). If there is a concern for the environment then because of its 'natural resources' upon which the company 'depend[s]' (McCormick, 2015, p. 36) and because these are 'vital resources' for the company (Rio Tinto, 2015, p. 13). Further, in accounting nature only "exists" if its value can be measured and thus represented (Cooper, 1992; Hines, 1992). By focusing on financial value as the only differentiating factor between the individual parts of nature recognised by accounting (i.e. different assets and liabilities implicating nature), the multiplicity and richness of difference within nature has been made invisible. Similar processes are also at work in accounting representations of women. An important consequence of this abstraction and categorisation is that the possibility of solidarity based on common experience, feeling, relatedness and empathy between women and nature has been eradicated: patriarchal power has successfully mobilised accounting in sustaining the oppression of nature and women.

Another example of how the binary human/nature has shaped accounting are attempts to categorise accounting, most notably the distinction between social accounting and environmental accounting. This categorisation reflects a variant of the human/nature

\footnotetext{
11 Accounting's role in sustaining power relationships has been highlighted in the critical accounting literature for some time and from different theoretical perspectives (for example, Cooper and Sherer, 1984; Armstrong1987; Miller and O’Leary, 1987).

${ }^{12} \mathrm{My}$ purpose here is to provide illustrations from representations of nature in CSR reports.
} 
binary, namely the binary society/nature. This becomes evident if we take a closer look at the relationship between society and the environment (nature) in this categorisation. Social accounting focuses amongst several issues directly related to society also on the environment, with the environment being a subset of the social (see, for example, ; Gray, 2002 al, 1996). We can read this as the social being the dominant part in this relationship and the environment (nature) the subordinate part without name and only visible to the extent that the social deems it to be of relevance. In contrast, in environmental accounting the environment (nature) is the part with a name but it is a part without a relationship. Environmental accounting is thus not the reversal of social accounting, that is it is not part of a relationship in which it plays the dominant role and society the subordinate one. Environmental accounting, in being devoid of any relationship with society, has achieved an aura of rationality and scientific neutrality, which allows every aspect of the environment to be quantified, measured and represented through an accounting focused on numerical targets and financial values, that is through an accounting reflecting male values (cf. Hines, 1992).

Having summarised from an ecofeminist perspective key elements of a critique of the representation of nature in CSRR, I now turn to an exploration of how the limitations I have summarised might be overcome in the design of new accountings, with better representations of nature. This section is deliberately speculative and concerned with potentialities rather than actualities as I believe that we should be imaginative in our attempt to envision new accountings, which go beyond Western dichotomous thinking. This is a challenging task because of the embeddedness of dichotomies in Western culture and experience: we currently seem to know no other way of thinking. But Western history tells us that this has not always been the case and that we have the potential to change the way we think (see, for example, Merchant, 1980; Romstötter, 2015). And, if we move beyond a Western focus then we quickly and reassuringly become aware that today in other cultures human identity in relation to nature is constructed in ways that emphasise wholeness, interconnectedness and relatedness (see, for example, Gallhofer et al, 2000; Greer and Patel, 2000).

\section{Inspiration from ecofeminist theorising for the design of new accountings for nature: introducing corporate nature responsibility $(\mathrm{CNR})$ and corporate nature responsibility reporting (CNRR)}

Andrew (2000, p. 212) has suggested that ecofeminism is about 'rearticulating the way that we live within the world'. This rearticulation requires an understanding of humans as part of nature, a move away from the dichotomous "either/or" to the relational "and" and a view of 'a person as a self-in-relation' (Nhanenge, 2011, p. 439). This has significant implications for all spheres of life, including social practices such as accounting: what we deem appropriate actions and goals in the context of Western dualism might no longer have validity or lose their legitimacy. It is of interest to explore the possible implications of such a change in the way of seeing for the design of new accountings. As accounting is an embedded practice, such an exploration has to go beyond a narrow focus on the technical aspects of accounting and include perceptions of the responsibilities of corporations and organisations more generally as well as accountability relationships. A focus on the construct corporate social responsibility, which is a key rationale and motivation for CSRR is thus an appropriate starting point. 
The Western notion of CSR currently in use reflects Western binary thinking, which narrows and delimits the radical potential of the construct. The dichotomy underpinning and shaping CSR in the context of nature is a variant of the human/nature dichotomy, namely corporation/nature with the company being the dominant and active part. The environment - as evident in definitions of CSR (Carroll, 2008; Crane et al, 2008; Dahlsrund, 2008) - neatly fits into a defined category with fixed boundaries. Further, what precisely a company's responsibility is in relation to the environment depends on what the company wants it to be. Thus, reporting, which is motivated by and reflects a Western notion of CSR, will only ever be able to provide accounts of nature (including humans) that are at best partial, dominate and exploit nature (including humans) and only too often render it invisible. We therefore need to rework the Western notion of corporate social responsibility if we are concerned to go beyond current representations of nature in company reporting.

A possible starting point for a rethinking of the Western notion of corporate social responsibility is the holistic notion of nature advocated by ecofeminists. This notion implies a move away from the construct "corporate social responsibility" (CSR) to the construct "corporate nature responsibility" (CNR). Focusing on CNR rather than CSR has significant implications, notably on how companies are governed and managed and the way they report to their stakeholders. I illustrate this with reference to the goal of the firm, the notion of accountability and the design of corporate nature responsibility reporting (CNRR).

The goal of the firm as understood in the Anglo-American context is to maximise wealth for the benefit of shareholders (Lumby and Jones, 2003). This perspective sees nature as a resource that can be legitimately used by (wo)men in the process of maximising wealth, the only restriction being broadly defined legal boundaries. For CNR, such a position would be untenable as wholeness, relatedness and interconnectedness have to be considered. The goal of the firm therefore has to be redesigned from an ecofeminist perspective, namely: wealth creation in the context of wholeness, interconnectedness and relatedness, which encompasses respect, appreciation, non-exploitation, equality and care for all - in other words, nature.

CNR also alters accountability relationships. Neither a narrow accountability to shareholders nor a wider accountability to stakeholders (Gray et al, 1996; Swift, 2001; O'Dwyer, 2003) appropriately captures the complex web of accountabilities that a corporation is part of in a context of wholeness, interconnectedness and relatedness. Current accountability relationships are between two parties: the company and its stakeholders. A key issue here is that only specific stakeholder interests are heard whereas others are silenced. Stakeholder groups are also mostly seen as universal groups, such as, suppliers, government, society and the environment. Further, the focus of the accountability relationship as evident in current reporting practice is one-dimensional and one-directional going from the organisation to its stakeholders. Accountability in the context of wholeness, interconnectedness and relatedness, however, considers in addition to the accountability relationships emanating from the company to individual stakeholder groups also accountabilities between these stakeholder groups and accountabilities of these stakeholder groups to the company itself. A consideration of the web of accountabilities in a context of wholeness, interconnectedness and relatedness can enhance awareness of how the actions of a corporation can have a myriad of impacts and effects on individual parts of the system as well as the system as a whole and in turn on the corporation itself. This 
means that impact on individuals, groups or society can no longer be seen in isolation from impact on, for example, animals, plants, water and the whole ecosystem. Further, in any attempt to unravel and depict the web of accountabilities a corporation is embedded in, difference within individual elements of the web of accountabilities has to be an integral part of analysis and communication.

My elaborations so far have already indicated that a rethinking and reconstruction of CSR as CNR has important implications for the reporting of companies. Next, I explore in more detail issues and elements of relevance for the design of accountings that would provide meaningful information in the context of CNRR.

\section{Envisaging CNRR: a sketch of key elements}

Although CSR reporting takes place on a voluntary basis most CSR reports to date adhere to the Global Reporting Initiative's (GRI) reporting guidelines, which have become globally accepted. Such a framework, however, does not exist for CNRR. Envisaging CNRR therefore needs to begin with sketching the elements of a framework for the design and production of CNR reports.

From an ecofeminist perspective a framework for the design and production of CNR reports has to go beyond Western dualism, embrace wholeness, interconnectedness and relatedness and the ecofeminist notions of nature and the goal of the firm. The complexities involved in CNRR raise the question whether one report published by the company itself can provide all the information required: even increased disclosure would still only reflect one perspective, namely that of the company. Dualism would also still shape the reporting of the active company to the passive other. Going beyond dualism in the context of CNRR thus requires acknowledging the equal validity of a multiplicity of reports about the same company, which are written from the perspective of and by different authors - one of those authors being the company itself. The range of authors highlights difference, an important element of CNRR as suggested by an ecofeminist perspective. Current practices of counter accounting, silent accounting and shadow accounting already indicate that different and important insights can be gained about the same company from the perspectives of authors who are not representing the view of the company (Gallhofer et al, 2006; Dey, 2007; Dey et al, 2010; Boiral, 2013; Dey and Gibbon, 2014; Apostol, 2015; Thomson et al, 2015; Lehman et al, 2016). These reports are, however, also problematic when viewed from an ecofeminist perspective: aiming to counter the official reports of companies they reflect a problematic Western dualism (i.e. official reports/unofficial reports).

Content and form are important elements of a framework for CNRR. Below I outline key principles rather than offer precise prescriptions, which should be considered in deciding upon content and form of CNR reports. Such an approach is in line with my attempt to provide a sketch of the key elements of a framework for CNRR. It also reflects my view that the design process in the context of CNRR has to be participatory to reflect wholeness, interconnectedness and relatedness (c.f. Gallhofer et al, 2015).

The point of view adopted in the reporting is important as it significantly shapes the content and form of CNRR. Point of view is related to authorship and reflects the authors' own subject positions and experiences. It is of note that although authors of counter reports - as currently produced - reflect different points of view these are still 
anthropocentric, which from an ecofeminist perspective is problematic. CNR reports should therefore also adopt the point of view of non-humans. Despite the limitations of such a mediated perspective of non-humans the attempt to represent the point of view of non-humans can draw attention to issues, which otherwise might not be seen or taken for granted. This point can be illustrated with reference to literature.

The Japanese writer Sōseki Natsume famously adopted the perspective of a cat in his novel I am a Cat (Natsume, 2002). ${ }^{13}$ In the novel an unwanted and wandering kitten without name observes and comments upon humans. Through adopting the 'device of dealing with a human world through animal eyes' (Ito and Wilson, 2002, p. ix) Natsume not only provided a critical commentary of the social changes of the Meiji area but also drew attention to how human actions can adversely affect animals. For example, the kitten observes: 'Living as I do with human beings, the more that I observe them, the more I am forced to conclude that they are selfish' (Natsume, 2002, p. 6). The cat also reminds us that human beings do not carefully observe non-humans and often treat them as undifferentiated and universal, which enhances the perception that animals are objects without feelings and individuality:

To the casual observer it may appear that all cats are the same facsimiles in form and substance, as indistinguishable as peas in a pod; and that no cat can lay claim to individuality. But once admitted to feline society, that casual observer would very quickly realize that things are not that simple... (Natsume, 2002, p. 19)

The passage from the novel powerfully illustrates how a switch in point of view can draw attention to the negative impact that our actions as humans have on non-humans, something humans normally do not consider. CNRR, which adopts a holistic approach in relation to experiences, therefore ought to contain reports, which are written from the mediated point of view of, for example, animals, plants, the sea and the air. A whole range of CNR reports about one company written from different perspectives can therefore draw attention to wholeness, interconnectedness and relatedness. And, most importantly, they can be an impetus for humans to change the way they see themselves and act in relation to nature. What precisely is reported in the various CNR reports of a company then depends on who is reporting and from what perspective. ${ }^{14}$

Another important issue in the context of CNRR is the form in which CNR information is reported. New forms to communicate the content of CNRR thus need to be explored. To gain inspiration, we can again turn to art. Gallhofer and Haslam (1996), focusing on radical German art during the first half of the twentieth century, have shown that forms of representation deployed by artists can be of relevance for accounting. Below I illustrate this for the case of CNRR.

In the context of CNRR form can be used to communicate complexity. It is reasonable to argue that communicating wholeness, interconnectedness and relatedness is easier and more effective through visual representations than through narratives. One visual image can capture wholeness and differentiation through showing all the individual parts that

\footnotetext{
${ }^{13}$ I would like to thank Akira Yonekura for drawing my attention to this novel.

${ }^{14}$ In terms of the CNR report of the company, there could still be specific requirements to report information, which reflect, for example, the legal and other regulatory contexts or specific requirements of stakeholders.
} 
make up the "whole". An interesting art form that can be mobilised to depict wholeness in CNRR is collage.

The collage in Table 1 shows a landscape: mountains, a river, villages and a sky with clouds. In the middle of the mountain there is a big red shape. The colour red indicates a wound - maybe an open cast mine or logging of virgin woods, in any case something that hurts nature. The big red shape is littered with small white rectangular shapes with numbers on them. These shapes symbolise species (e.g. animals, plants, maybe humans if they live in the area). Yellow, green and blue threads connect the white shapes indicating interconnectedness and relatedness. There are several red threads meandering from the big red shape to the villages, river and the sky (air), which shows again interconnectedness. In addition to the red threads that connect the shape to its surroundings a red grid covers the red shape but at the same time also goes beyond the borders of the shape. It encroaches slowly into the areas next to the shape and seems to take over more and more of its surroundings. This web indicates the subtle and not easily recognisable impact on the context in which the shape is located. Sometimes a piece of web seems to have broken off and now covers a village or a cloud. The red shape impacts upon the town and the cloud through the piece of web but the connection is invisible.

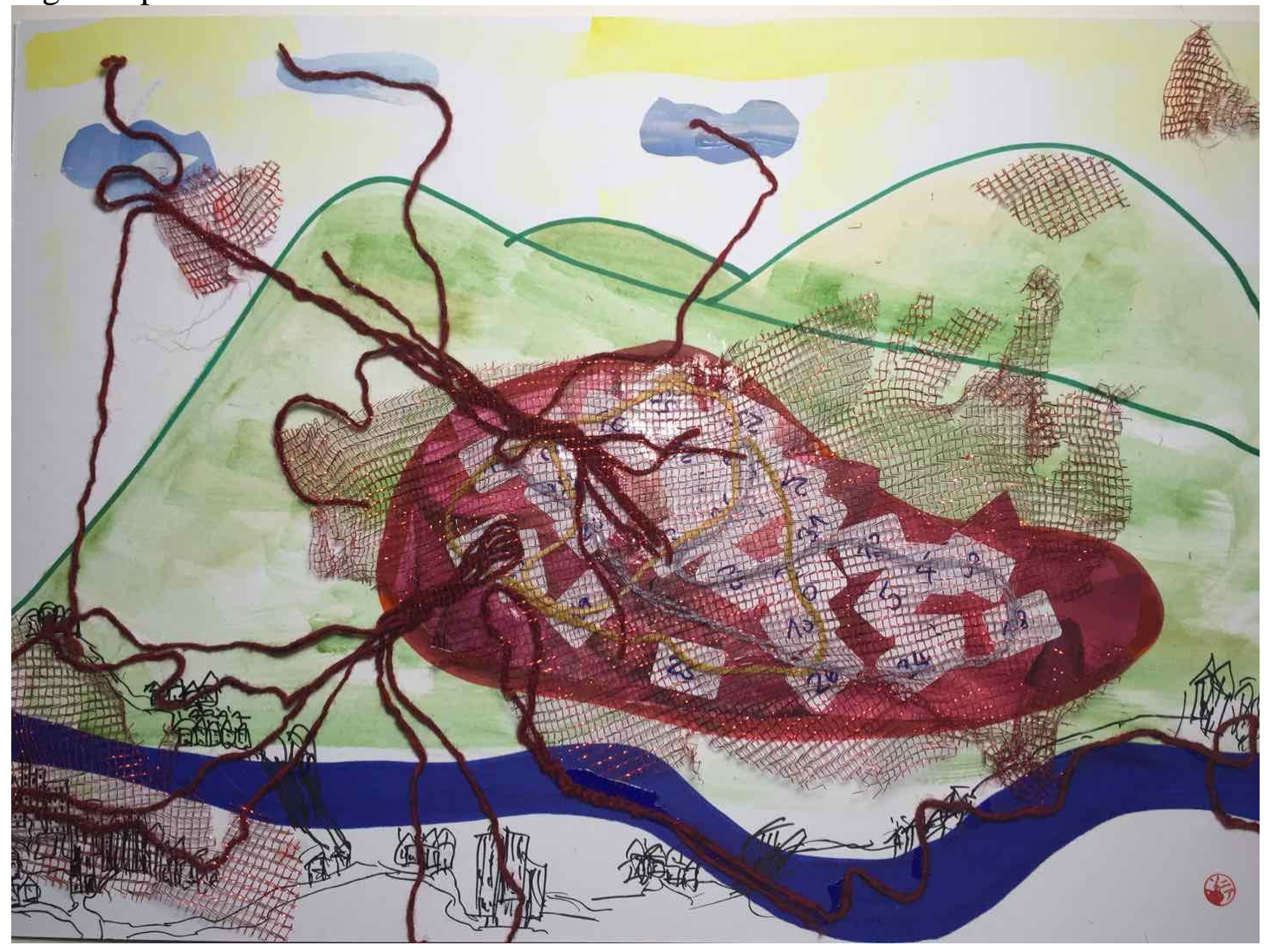

Table 1: "CNRR of Company XY Mining” by the author 
The above collage is one way of telling a story of the impact of corporate activities on nature. And, most importantly, it is my way of representing this story, i.e. this is my CNR report. ${ }^{15}$

Further, in visual representations we can deploy a change of perspective by changing our focus: when we look at an object then we can focus in or focus out. Changing focus will change how we perceive and react to the object we focus upon. For example, the two photographs in Table 2 show how through "zooming in" and "zooming out" visibilities and invisibilities are created. The visibilities created are powerful, draw attention to interrelationships and encourage a reconsideration of actions. "Zooming in" and "zooming out" in photography or other visual representations (such as film, collage, paintings) are an appropriate way of communicating wholeness, interconnectedness and relatedness.

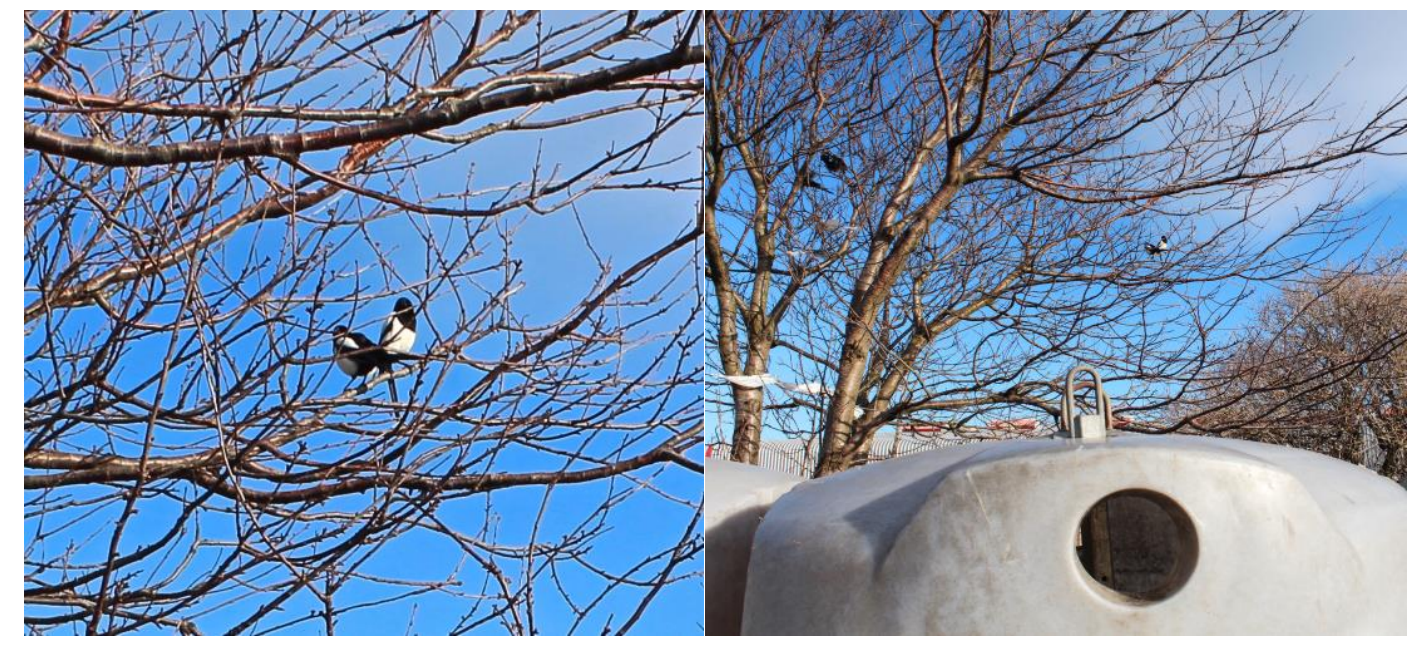

\begin{tabular}{|l|l|}
\hline Photo 1A - Zooming In: & Photo 1B - Zooming Out: \\
\hline $\begin{array}{l}\text { Two magpies on the branches of a tree and a } \\
\text { beautiful blue sky. Peaceful, relaxing, a joy to } \\
\text { look at. I wished I was there... }\end{array}$ & $\begin{array}{l}\text { The same two magpies on the branches of } \\
\text { the same tree but this time sharing the tree } \\
\text { with toilet paper, pieces of plastic bags and } \\
\text { black bin liners. The sky is still blue but I } \\
\text { definitely don't want to be there... }\end{array}$ \\
\hline
\end{tabular}

Table 2: "Zooming in \& Zooming out" by the author

In addition to visual art, other art forms, such as music, dance and plays are effective ways of communicating CNR information. Enacting a CNR report - for example, as a play or dance - can involve those affected by the operations of a company in the enactment. This experience can unite and give strength to engage in emancipatory change. Watching a CNR report being enacted also provides valuable insights and experiences to the audience, especially if the enactment involves audience participation. Through the process of enactment wholeness, interconnectedness and relatedness are made visible. To communicate CNR information videos, films, photographs, paintings, music - the list is endless - can all be transmitted using the Internet and social media.

\footnotetext{
${ }^{15} \mathrm{I}$ am exploring issues concerning the production of CNR reports in another research project. For the purposes of this paper here my brief elaboration is intended to provide an illustration of the relevance of form in the context of CNRR.
} 
In my discussion of key issues related to content and form of CNRR I could only begin to draw attention to some of the possibilities. More ideas for content and appropriate and effective ways of communicating will emerge, be discovered, invented, re-invented and reworked as people get involved in producing CNR reports. And, there will be increased experimentation of how to include those and their experiences who currently have no voice, for example, through developing an emancipatory and participatory design process for CNRR.

Having explored elements of the design of CNRR I next discuss elements of an emancipatory praxis in the context of a concern to realise the potential of CNRR. This also includes strategies for change aimed at developing a comprehensive CNRR.

\section{Implications of an ecofeminist lens for an emancipatory praxis in the context of a concern to realise the potential of CNRR}

So far, I have offered a critique of CSRR as currently practiced and developed a sketch of key elements of CNRR as a response to this critique. The task that remains is an exploration of aspects of a praxis, which would help engender the transformation from CSRR as currently practiced to CNRR as envisaged. This task is challenging. First, multiple pathways for change, which reflect a whole variety of different voices, must be negotiated. This can be operationalized, as accounting researchers adopting a newpragmatist perspective have argued, through "chains of equivalence" (Mouffe, 1988) that link the diverse interests and struggles of different groups (Brown, 2009; Brown and Dillard, 2013a, b; Brown and Dillard, 2015; Brown et al, 2015; Dillard and Brown, 2015; Gallhofer et al, 2015; Dillard et al, 2016). Second, the desired outcome that is to be achieved will change in the process of transformation as more and different groups get involved and shape the design of CNRR thus taking it beyond what had initially been envisaged. Third, as change is incremental and moves along a continuum towards the envisaged desired outcome the changes occurring whilst travelling can themselves impact on both the pathway of transformation as well as the desired outcome (Gallhofer and Haslam, 2003; Gallhofer et al, 2015). Consequently, the transformation from CSRR as currently practiced to CNRR as envisaged is a complex process, with a high degree of uncertainty and unpredictability and involving multiple actors and sites.

It is of interest to consider whether CNRR itself can play a transformative role in the process of creating the conditions for it to be practiced widely. The view that one takes depends on how one theorises accounting in relation to the context in which it operates. Some might argue that CNRR as outlined here can only be practiced once the context in which it is embedded has changed, that is, once we have gone beyond Western dualism. The implications of a praxis reflecting this type of reasoning are at best depressing and most likely ecocidal (Clark, 2000, p. 62). A different view and one well-rehearsed in the literature (early examples being Burchell et al, 1980, 1985) stresses that changes to accounting do not occur in isolation but in interrelation with a dynamic context. The important insight from this argumentation is that CNRR does not change in isolation but always in interrelation with its context: practicing CNRR in the current context would thus begin to change both CSRR as currently practiced and the context (Gallhofer et al, 2015). The accounting literature focusing upon the accounting-emancipation interrelationship has especially highlighted the transformative potential of accounting and provided examples of its realisation (see for example, Gallhofer and Haslam, 1991, 2003, 2006, 2017; McNicholas and Barrett, 2005; Brown, 2009; Alawattage and Wickramasinghe, 2009; 
Spence, 2009; Jacobs, 2011; Molisa, 2011; Gallhofer et al, 2000, 2006, 2015; Kamla, 2015; Thompson et al, 2015). The insights of these studies encourage the realisation of the emancipatory and transformative potential of CNRR as part of an emancipatory praxis. The multiplicity of CNR reports and producers of these reports are central to an emancipatory praxis: the different and diverse visibilities they create can raise awareness and lead to transformative action. Such action can engender tangible changes in, for example, consumer behaviour, investment decisions and regulations as well as in perceptions, ways of seeing and thinking. For these changes to take place there needs to be a well-informed and broad user base. Education, the Internet and Social Media are important facilitators in this respect (Gallhofer et al, 2006; Saravanamuthu and Lehman, 2013). As the production and usage of CNR reports increases, companies might experience pressure to change their actions, which in turn can lead to voluntary changes in reporting practices. I am aware that voluntary changes in companies' reporting practices have been viewed with suspicion by accounting researcher, who have pointed to the danger of capture of radical and socially beneficial concepts and practices (see, for example, Owen et al, 2000; Milne and Patten 2002; O'Dwyer, 2003; Aras and Crowther, 2009; Killian and O'Regan, 2016). I agree that much of the voluntary disclosure of CSR information to date has been motivated by profit maximisation but at the same time I believe that capture can never be complete and if there is significant grassroots pressure and a shift in perceptions within society more generally positive change can be achieved.

In the process of the transformations outlined above it is vital that there is a willingness to learn from other cultures. Engaging with cultures other than the Western requires openness to doing things differently, including other ways of thinking. This is challenging for those who have been socialised in a Western context, in which the supremacy of Western ways of doing is assumed and only rarely questioned. These challenges can, however, be overcome through an awareness of the difficulties and a commitment to overcoming obstacles. The literature on accounting and indigenous peoples provides interesting insights into what can be learned from cultures other than the Western especially in relation to the human-nature interrelationship (see, for example, Gallhofer et al, 2000; Greer and Patel, 2000). This work draws attention to issues that are also relevant from an ecofeminist perspective and thus is especially helpful in the context of a concern with CNRR.

For me, the key - but also the most challenging - element of an emancipatory praxis in the context of CNRR is finding ways of moving beyond Western dualism and towards a subject position that is not in opposition to nature. King (1989, p. 126) has cogently argued:

The collision of modern industrial society with indigenous cultures has decimated these ancestral forms, but it may have brought white westerners into contact with forms of knowledge useful to us as we try to imagine our way beyond dualism, to understand what it means to be embodied beings on this planet. These traditions are often used as examples of nondualistic ways of life, at least which overcome nature/culture dualism. But human beings cannot simply jump off or out of history. These indigenous, embodied, earth-centred spiritual traditions are planting seeds in the imagination of people who are the products of dualistic cultures, but...they are not ways of being or systems of thought that can be adopted whole cloth by white westerners... 
The challenges King (1989) refers to are significant but in my view - a view shared by ecofeminists (Nhanenge, 2011) - they are not insurmountable and we therefore should not be discouraged. If we can envisage a different world, in which wholeness, interconnectedness and relatedness and a notion of nature reflecting these values are the norm, then we are on the path of achieving our goal.

It is of interest here to consider in more detail two interrelated areas for an emancipatory praxis in the context of CNRR, which are especially relevant for academics, namely education and research. Through teaching as well as research we can put CNRR on the agenda and promote this type of accounting. We can challenge Western thinking in our critique of the accountings currently practiced and offer different ways of seeing and different accountings. Discussion of CNR and CNRR is best facilitated through a pedagogy that reflects emancipatory learning objectives and ecofeminist theorising. The accounting literature concerned to develop a dialogic approach to education (McPhail, 2001; Stevenson et al, 2014) as well as attempts to develop emancipatory pedagogies in other disciplines (Tassoni, 1998) are a source of inspiration in this respect.

Research also plays an important role in the context of an emancipatory praxis concerned to move from CSR and CSRR to CNR and CNRR. Above I have introduced the new construct of CNR and provided a first sketch of key elements of a framework for CNRR. The challenge now is to further develop CNR and CNRR through research. Below I outline an agenda for research. This agenda reflects my interests, concerns and biases, and thus is a limited but hopefully not limiting agenda. If it engenders debate, raises new questions, explores new ideas, leads to new strategies and ways-forward then it is a good agenda.

\section{Agenda for CNR and CNRR research}

My elaborations of the broad areas that need to be further explored are structured according to the CSM and, where appropriate, illustrated with reference to endangered species.

In terms of the critique of accounting as currently practiced there is a need to further develop the critique of CSR and CSRR from an ecofeminist perspective. This should include a focus on more recent developments under the broad umbrella of CSRR, including accounting for biodiversity and extinction accounting. Current forms of alternative accounts (e.g. counter accounts, silent accounts and shadow accounts) and how they often reflect the key Western dichotomies society/nature, culture/nature and humans/nature, constitute important research focuses. Critically evaluating current official as well as alternative reporting practices will help identify similarities and differences and provide insights, which can inform strategies for change and enhance solidarity. The importance of research in the context of a critique of current accounting practices for the development of CNRR can be illustrated with reference to an example from extinction accounting, namely accounting for bees and pollinators (Atkins and Atkins, 2016; Atkins et al., 2016). ${ }^{16}$ Adopting an ecofeminist perspective research can enhance our

\footnotetext{
16 The focus of the papers in Atkins and Atkins (2016) is on reporting by the corporation whereas CNRR advocates a multiplicity of producers of CNR reports - one of those producers being companies. My brief examples of CNRR on bees and pollinators in this section thus build upon but go beyond Atkins et al (2016) and are intended to illustrate possibilities for further research.
} 
understanding of how Western constructions of accounting and the human-nature interrelationship have shaped the content and form of corporate reporting and alternative accounts on bees and pollinators. A critical appreciation of enabling as well as disabling aspects of these practices can facilitate improvements as well as encourage and inform the design of new accountings for bees and pollinators in the context of a concern with CNR.

In terms of envisaging CNR and CNRR, we need research that further explores delineations of CNR and CNRR. In this paper, I have provided a brief delineation of CNR and a brief sketch of a framework for CNRR. The challenge now is to explore through research how CNR and CNRR could be further developed. A focus on alternative accounts is especially relevant in this context. More research is needed that investigates the emancipatory possibilities of alternative accounts in terms of their design and production processes and their content and form. Understanding the various design and production processes of alternative accounts is highly relevant as CNR advocates a multiplicity of different producers of CNR reports. This can again be illustrated with reference to a concern to account for endangered species. If one is aiming to produce a report, which highlights the impact of corporations on endangered species, research can provide ideas and inspiration for the design and production process of such a CNR report in terms of whom to involve, what to report and how to report in order to create visibilities, enhance awareness and engender change in behaviour. Especially important in the context of a concern with CNR and the particular human-nature interrelationship it advocates, is research that explores how CNR reports can best make visible the interrelationship between the wellbeing of humans and a company's impact on endangered species. Further, building upon counter-accounting practices (Gallhofer et al, 2006; Boiral, 2013) and critiques of current CSRR practices, researchers can design examples of CNR reports to encourage wider engagement with CNR and CNRR. In order to develop CNR reports we also need a better and more detailed understanding of the human-nature interrelationship in cultures other than the Western and an exploration of how these human-nature interrelationships can inform the design and production of CNR reports. Research can here draw attention to the limitations of an anthropocentric perspective in reporting and encourage producers of CNR reports on, for instance, endangered species to adopt different ways of seeing in their CNR reports. Further, studies exploring the role of the Internet and social media in promoting CNR and CNRR would add valuable insights and facilitate attempts to communicate CNR information widely and effectively. Focusing again on the example of bee and pollinator extinction, an understanding of the many types of representation that the Internet offers can facilitate the design of reports for particular audiences, for instance, reports aimed at children, farmers or policy makers. Action research and the co-production of CNR reports can here provide interesting insights into the design process.

In terms of the type of emancipatory praxis outlined earlier, there are several contributions research can make. To develop effective pedagogies, which help promote CNR and CNRR we need a better understanding of the role that current accounting education plays in reenforcing Western dichotomous thinking in relation to nature and the representation of nature through accounting. These insights can then facilitate the exploration and design of pedagogies that would challenge Western dichotomous thinking and enable pupils and students to adopt a critical and holistic stance in relation to accounting and the representation and repression of nature. And, it can inform the design of dialogic and critical pedagogies. Here, action research again plays an important role. For instance, in the context of co-producing a CNR report on some endangered species, such as 
orangutans, gorillas, tigers and elephants with school children the researcher can experiment with different pedagogies and aim to gain insights into the development of pedagogies that would help challenge Western ways of thinking and enhance pupils' understanding of different ways of relating to these animals. Further, research can provide insights into the type of strategies that can be applied to engender the change from CSR to CNR and from CSRR to CNRR. Such research needs to especially focus on civil society as it plays a key role in the production of CNR reports. We therefore need a better appreciation of what encourages or discourages people to engage in the production of CNR reports.

Research investigating the issues addressed above must be interdisciplinary and mobilise a whole range of different methodologies and methods so as to capture the complexities involved in CNR and CNRR. And, most importantly, there needs to be a willingness on the part of the individual researchers to engage, work together and share insights in the pursuit of the common goal, namely going beyond the repressive, exploitative and limiting interrelationship between humans and nature as evident in CSR and CSRR and moving towards the holistic and enabling interrelationship that is evident in CNR and CNRR. A better understanding of CNR and CNRR based on research as outlined above can inform engagement with corporations as well as the multiplicity of other producers of CNR reports.

\section{CONCLUDING COMMENTS}

In this paper I outlined an ecofeminist lens for the critique of CSR and CSRR. The theoretical lens highlighted how binary or dichotomous thinking had shaped western understanding and representations of the human-nature interrelationship, which are also reflected in accounting representations of nature. As a way of going beyond Western dualism, the ecofeminist lens advocated wholeness, interconnectedness and relatedness and a notion of nature, in which humans are part of nature. I applied this feminist lens to the critique of CSR and CSRR. Based on the insights from this critique I introduced the concepts of CNR and CNRR in an attempt to go beyond Western dualism. I broadly defined the CNRR for a company as involving the production of a multiplicity of reports written by different authors - one of them being the company itself - from a multiplicity of perspectives that provide relevant information about how well the company had achieved its goal in the context of a concern with CNR. I then offered a preliminary sketch of key elements of CNR and CNRR and considered key aspects of an emancipatory praxis in the context of CNRR. A research agenda was developed to stimulate work that would enhance our understanding of CNR and CNRR and contribute to the further development of this type of accounting.

My elaborations suggest that in order to overcome the limitations of CSR and CSRR a corporation ought to focus on its broader and holistic corporate nature responsibility $(C N R)$. And, it should provide a CNR report, as part of the holistic corporate nature responsibility reporting (CNRR) concerned with the performance of the company in the context of CNR. The CNR reports constituting the CNRR for a particular company have to be produced by a multiplicity of authors - one of them being the company the CNRR focuses upon - from their perspectives as well as the perspectives of those that cannot be heard because they cannot speak for themselves (e.g. animals and plants). And, policy makers ought to shift their focus from the limiting construct of corporate social responsibility to the enabling construct of corporate nature responsibility. 
I am aware that from a western standpoint the task of challenging and changing western dichotomous thinking is daunting but if we bear in mind that our relationship with nature as the ecofeminist critique has highlighted - is socially constructed then we can begin to reconstruct it. And that, of course, would mean that we are beginning to change the "master story". This paper is thus motivated by a concern to engender debate, which challenges and goes beyond Western ways of thinking, is non-dominant, non-binary, inclusive and holistic and engages with and is willing to learn from non-Western ways of seeing the human-nature interrelationship. For me such engagement is an important element of an emancipatory praxis.

An important question still remains: What is to be achieved as a result of going beyond Western dualism and changing the way we think? For me, through challenging Western ways of thinking we can engender change in terms of how we as humans relate to other humans and to the non-human world. As a result of this changed behaviour the world would be a better place to live in, a kinder place, a healthier place and a happier place where there is a sense of harmony and well-being for all. The following quote by Rosemary Radford Ruether (2005, p. 131) highlights this point:

Is another world possible? Can we create a different world system from that being hammered in place by transnational corporations, the World Bank, the International Monetary Fund, the World Trade Organization, and the politicians representing the wealthy elites? Can a different way of relating human beings to each other and to the earth emerge that would manifest equity and sustainable community? Perhaps the way we think is the heart of the problem [my emphasis].

So, let's begin to think differently and see what is possible... 


\section{REFERENCES}

Alawattage, C. and Wickramasinghe, D. (2009), "Weapons of the weak: Subalterns' emancipatory accounting in Ceylon Tea", Critical Perspectives on Accounting, Vol. 22, pp. 379-404.

Andrew, J. (2000), "The accounting craft and the environmental crisis: reconsidering environmental ethics", Accounting Forum, Vol. 24, No. 2, pp. 197-222.

Apostol, O. M. (2015), “A project for Romania? The role of the civil society's counteraccounts in facilitating democratic change in society", Accounting, Auditing and Accountability Journal, Vol. 28, No. 2, pp. 201-241.

Aras, G. and Crowther, D. (2009), "Corporate sustainability reporting: a study in disingenuity?”, Journal of Business Ethics Supplement, Vol. 87, pp.279-88.

Archel, P., Husillos, J., Larrinaga, C. and Spence, C. (2009), "Social disclosure, legitimacy theory and the role of the state", Accounting, Auditing and Accountability Journal, Vol. 22 No. 8, pp. 1284-307.

Armstrong, P. (1987), "The rise of accounting controls in British capitalist enterprises", Accounting, Organizations and Society, Vol. 12, No. 5, pp. 405-4.

Atkins, J. and Atkins, B. (Eds) (2016), The Business of Bees: An Integrated Approach to Bee Decline and Corporate Responsibility, Sheffield: Greenleaf.

Atkins, J., Barone, E., Maroun, W. and Atkins, B. (2016), "Bee accounting and accountability in the UK", in Atkins, J. and Atkins, B. (Eds) (2016), The Business of Bees: An Integrated Approach to Bee Decline and Corporate Responsibility, Sheffield: Greenleaf, pp. 198-211.

Birkeland, J. (1993), "Ecofeminism: linking theory and practice", in: Gaard, G. (ed.), Ecofeminism: Women, Animals, Nature, Philadelphia: Temple University Press, pp. 13-59.

Boiral, O. (2013), "Sustainability reports as simulacra? A counter-account of A and A+ GRI reports", Accounting, Auditing and Accountability Journal, Vol. 25, No. 7, pp. 10361071.

Broadbent, J. (1998), "The gendered nature of 'accounting logic': pointers to an accounting that encompasses multiple values", Critical Perspectives on Accounting, Vol. 9, pp. 267-297.

Brown, J. (2009), "Democracy, sustainability and dialogic accounting technologies: Taking pluralism seriously", Critical Perspectives on Accounting, Vol. 20, pp. 313-341.

Brown, J. and Dillard, J. (2013a), "Agonizing over engagement: SEA and the 'death of environmentalism' debate”, Critical Perspectives on Accounting, Vol. 24, pp. 1-18.

Brown, J. and Dillard, J. (2013b), "Critical accounting and communicative action: on the limits of consensual deliberation", Critical Perspectives on Accounting, Vol. 24, pp. 176190. 
Brown, J. and Dillard, J. (2015), "Dialogic accountings for stakeholders: on opening up and closing down participatory governance", Journal of Management Studies, Vol. 52, pp. 961-985.

Brown, J., Dillard, J,. and Hopper, T. (2015), “Accounting, accountants and accountability regimes ion pluralistic societies: Taking multiple perspectives seriously", Accounting, Auditing and Accountability Journal, Vol. 28, pp. 626-650.

Buhr, N. (2011), "Indigenous peoples in the accounting literature: time for a plot change and some Canadian suggestions", Accounting History, Vol. 16, pp. 139-160.

Buhr, N. and Reiter, S. (2000), "Environmental disclosure and accountability: an ecofeminist perspective", in: Proceedings of the Sixth Interdisciplinary Perspectives on Accounting Conference, University of Manchester.

Burchell, S., Clubb, C. and Hopwood, A. (1985), "Accounting in its social context: Towards a history of value added in the United Kingdom", Accounting, Organizations and Society, Vol. 10, No. 4, pp. 381-413.

Burchell, S., Clubb, C., Hopwood, A., Hughes, J. and Nahapiet, J. (1980). "The roles of accounting in organizations and society", Accounting, Organizations and Society, Vol. 5, No. 1, pp. 5-27.

Burritt, R.L. and Schaltegger, S. (2010), "Sustainability accounting and reporting: fad or trend?", Accounting, Auditing and Accountability Journal, Vol. 23 No. 7, pp. 829-846.

Carroll, A. B. (2008), "A history of corporate social responsibility: concepts and practices", in: Crane, A., McWilliams, A., Matten, D. Moon, J. and Siegel, D. S. (Eds), The Oxford Handbook of Social Responsibility, Oxford: Oxford University Press, pp. 1946.

Christ, C. P. (2003), She Who Changes: Re-imaging the Devine in the World, New York: Palgrave Macmillan.

Clark, J. (2000), "The matter of freedom: Ecofeminist lessons for social ecology", Capitalism, Nature Socialism, Vol. 11 No. 3, pp. 62-80.

Cooper, C. (1992), "The non and nom of accounting for (m)other nature", Accounting, Auditing and Accountability Journal, Vol. 5 No. 3, pp. 16-39.

Cooper, C. and Senkl, D. (2016), “An(other) truth: a feminist perspective on KPMG's true value", Sustainability Accounting, Management and Policy Journal, Vol. 7, No. 4, pp. 494-516.

Cooper, D. J. and Sherer, M. (1984), "The value of corporate accounting reports: Arguments for a political economy of accounting", Accounting, Organizations and Society, Vol. 9, Nos. 3-4, pp. 207-232.

Crane, A., McWilliams, A., Matten, D. Moon, J. and Siegel, D. S. (2008), “The corporate social responsibility agenda", in: Crane, A., McWilliams, A., Matten, D. Moon, J. and Siegel, D. S. (eds), The Oxford Handbook of Social Responsibility, Oxford: Oxford University Press, pp. 3-15. 
Dahlsrud, A. (2008), "How corporate social responsibility is defined: an analysis of 37 definitions", Corporate Social Responsibility and Environmental Management, Vol. 15, pp. 1-13.

De Beauvoir, S. (2010), The Second Sex, translated by C. Borde and S. MalovanyChevallier, London: Vintage Books.

Dey, C. (2007), "Developing silent and shadow accounts", Chapter 16, in: O'Dwyer, B., Bebbington, J. and Unerman, J. (Eds), Sustainability, Accounting and Accountability, London: Routledge, pp. 307-326.

Dey, C. and Gibbon, J. (2014), "External accounts", in Bebbington, J., Unerman, J. and O'Dwyer, B. (Eds), Sustainability, Accounting and Accountability, $2^{\text {nd }}$ edition, Routledge, London, pp. 108-123.

Dey, C., Russell, S. and Thomson, I. (2010), "Exploring the potential of shadow accounts in problematizing institutional conduct", in Ball, A. and Osborne, S. (Eds), Social Accounting and Public Management, Routledge, London, pp. 64-78.

Dillard, J. and Brown, J. (2015), "Broadening out and opening up: An agonistic attitude toward progressive social accounting", Sustainability, Accounting, Management nad Policy Journal, Vol. 6, pp. 243-266.

Dillard, J., Yuthas, K. and Baudot, L. (2016), Dialogic framing of accounting information systems: Lessons from, and for, microfinance", International Journal of Accounting Information Systems, Vol. 23, pp. 14-27.

Gaard, G. (1993), Living interconnections with animals and nature", in: Gaard, G. (ed.), Ecofeminism: Women, Animals, Nature, Philadelphia: Temple University Press, pp. 1-12.

Gaard, G. (2015), "Ecofeminism and climate change", Women's Studies International Forum, Vol. 49, pp. 20-33.

Gaard, G. and Murphy, P. D. (Eds) (1998), Ecofeminist Literary Criticism: Theory, Interpretation, Pedagogy, Urbana and Chicago: University of Illinois Press.

Gallhofer, S. (1992), "M[othering] view on: 'The non and nom of accounting for (m)other nature", Accounting, Auditing and Accountability Journal, Vol. 5 No. 3, pp. 40-51.

Gallhofer, S. and Haslam, J. (1991), "The Aura of Accounting in the Context of a Crisis: Germany and the First World War", Accounting, Organizations and Society, Vol. 16, Nos. 5/6, pp. 487-520.

Gallhofer, S. and Haslam, J. (1996), “Accounting/art and the emancipatory project: some reflections", Accounting, Auditing and Accountability Journal, Vol. 9, No. 5, pp. 23-44.

Gallhofer, S. and Haslam, J. (1997), "The direction of green accounting policy: critical reflections", Accounting, Auditing and Accountability Journal, Vol. 10, No. 2, pp. 148174.

Gallhofer, S. and Haslam, J. (2003), Accounting and Emancipation: Some Critical Interventions, Routledge, London. 
Gallhofer, S. and Haslam, J. (2006), "Mobilising accounting in the radical media during the First World War and its aftermath: the case of Forward in the context of Red Clydeside", Critical Perspectives on Accounting, Vol. 17, Nos. 2/3, pp. 224-252.

Gallhofer, S. and Haslam, J. (2008), "The Possibilities of accounting in the global context: Critical reflections on accounting and the Internet as a new technology of communication", in: Lada, M. and Kozarkiewicz, A. (eds), (2008), Rachinkowosc: W Otoczeniu Nowych Technologii, Warszawa: Wydawnictwo C. H. Beck, pp. 11- 30.

Gallhofer, S. and Haslam, J. (2017), "Some reflections on the construct of emancipatory accounting: shifting meaning and the possibilities of a new pragmatism", Critical Perspectives on Accounting.

Gallhofer, S., Gibson, K., Haslam, J., McNicholas, P. and Takiari, B. (2000), "Developing Environmental Accounting: Insights from Indigenous Cultures", Accounting, Auditing and Accountability Journal, Vol. 13, No. 3, pp. 381-409

Gallhofer, S., Haslam, J. and Yonekura, A. (2015), “Accounting as differentiated universal for emancipatory praxis: Accounting delineation and mobilisation for emancipation(s) recognising democracy and difference", Accounting, Auditing and Accountability Journal, Vol. 28, No 5, pp. 846-874.

Gallhofer, S., Haslam, J., Monk, E. and Roberts, C. (2006), “The Emancipatory Potential of Online Reporting: The Case of Counter Accounting", Accounting, Auditing and Accountability Journal, Vol. 19, No. 5, pp. 681-718.

Gebara, I. (1999), Longing for Running Water: Ecofeminism and Liberation, Fortress Press, Minneapolis.

Glazebrook, T. (2014), "Ecofeminism”, in Michalas, A.C. (Ed.), Encyclopedia of Quality of Life and Well-Being Research, Springer, New York, pp. 1765-1770.

Godfrey, P. (2005), "Diane Wilson vs. Union Carbide: ecofeminism and the elitist charge of 'essentialism"”, Capitalism, Nature, Socialism, Vol. 16 No. 4, pp. 37-56.

Gray, R. (2002), "The social accounting project and accounting organizations and society: Privileging engagement, imaginings, new accountings and pragmatism over critique", Accounting, Organizations and Society, Vol. 27, No. 7, pp. 687-708.

Gray, R. and Bebbington, J. (2000), "Environmental accounting, managerialism and sustainability: is the planet safe in the hands of business and accounting?", Advances in Environmental Accounting and Management, Vol. 1, pp. 1-44.

Gray, R. and Milne, M. (2002), “Sustainability reporting: who's kidding whom?”, Chartered Accountants Journal of New Zealand, Vol. 81 No. 6, pp. 66-74.

Gray, R. H., Owen, D. and Adams, C. (1996), Accounting and Accountability: Changes and Challenges in Corporate Social and Environmental Reporting, London: Prentice Hall.

Greer, S. and Patel, C. (2000), "The issue of Australian indigenous world-views and accounting", Accounting, Auditing and Accountability Journal, Vol. 13, No. 3, pp. 307329. 
Haynes, K. (2016), “Accounting as gendering and gendered: A review of 25 years of critical accounting research on gender", Critical Perspectives on Accounting.

Hines, R. D. (1992), Accounting: filling the negative space", Accounting, Organizations and Society, Vol. 17, No. 3/4, pp.313-341.

Irvine, S. and Helin, J. (2017), "A world for sale? An ecofeminist reading of sustainable development discourse", Gender, Work and Organization.

Ito, A. and Wilson, G. (2002), Introduction, in: Natsume, S. (2002), I am a Cat, Tokyo: Tuttle Publishing, pp. iv-X.

Jacobs, K. (2011), "Enlightenment and emancipation: Reflections for critical accounting research", Critical Perspectives on Accounting, Vol. 22, pp. 510-515.

Kamla, R. (2015), "Critical Muslim intellectuals' thought: Possible contributions to the development of emancipatory accounting thought", Critical Perspectives on Accounting, Vol. 31, pp. 64-74.

Keller, C. (1989), Feminism and the ethic of inseparability", in: Plaskow, J. and Christ, C. P. (eds), Weaving the Visions: New Patterns in Feminist Spirituality, San Francisco: Harper, pp. 256-265.

Kheel, M. (1991), "Ecofeminism and deep ecology", The Trumpeter, Vol. 8, No. 2, pp. 62-72.

Killian, S. and O'Regan, P. (2016), "Social accounting and the co-creation of corporate legitimacy", Accounting, Organizations and Society, Vol. 50, pp. 1-12.

King, Y. (1989), "Healing the wounds: feminism, ecology, and nature/culture dualism", in Jaggar, A. M. and Bordo, S. R. (eds), Gender/Body/Knowledge: Feminist Reconstructions of Being and Knowing, Rutgers University Press, New Brunswick and London, pp. 115141.

Lehman, C., Annisette, M. and Agyemang, G. (2016), "Immigration and neoliberalism: three cases and counter accounts", Accounting, Auditing and Accountability Journal, Vol. 29, No. 1, pp. 43-79.

Lombardi, L. (2016), "Disempowerment and empowerment of accounting: an indigenous accounting context", Accounting, Auditing and Accountability Journal, Vol. 29, No. 8, pp. $1320-1341$.

Lumby, S. and Jones, C. (2003), Corporate Finance: Theory and Practice, $7^{\text {th }}$ edition, London: Thomson.

Maunders, K. T. and Burritt, R. L. (1991), "Accounting and Ecological Crisis", Accounting, Auditing and Accountability Journal, Vol. 23, No. 7, pp. 9-26.

McNicholas, P. and Barrett, M. (2005), "Answering the emancipatory call: an emerging research approach 'on the margins' of accounting", Critical Perspectives on Accounting, Vol. 16, pp. 391-414. 
McPhail, K. (2001), "The dialectic of accounting education: from role identity to ego identity", Critical Perspectives on Accounting, Vol. 12, pp. 471-499.

Merchant, C. (1980), The Death of Nature: Women, Ecology and the Scientific Revolution, London: Wildwood House.

Merchant, C. (2005), Radical Ecology: The Search for a Livable World, $2^{\text {nd }}$ edition, New York: Routledge.

Merchant, C. (2013), Reinventing Eden: The Fate of Nature in Western Culture, $2^{\text {nd }}$ edition, New York: Routledge.

Miller, P. and O'Leary, T. (1987), "The construction of the governable person", Accounting, Organizations and Society, Vol. 12, No. 3, pp. 235-265.

Milne, M. J. and Patten, D.M. (2002), "Securing organizational legitimacy: an experimental decision case examining the impact of environmental disclosures", Accounting, Auditing and Accountability Journal, Vol. 15 No. 3, pp. 372-405.

Molisa, P. (2011), “A spiritual reflection on emancipation and accounting", Critical Perspectives on Accounting, Vol. 22, pp. 453-484.

Mouffe, C. (1988), "Radical democracy: modern or postmodern", in Ross, A. (Ed.), Universal Abandon? The Politics of Postmodernism, Edinburgh University Press, Edinburgh, pp. 31-45.

Natsume, S. (2002), I am a Cat, North Clarendon: Tuttle Publishing.

Nhanenge, J. (2011), Ecofeminism: Towards Integrating the Concerns of Women, Poor People, and Nature into Development, University Press of America, New York.

O'Dwyer, B. (2003), “Conceptions of corporate social responsibility: the nature of managerial capture", Accounting, Auditing and Accountability Journal, Vol.16, No. 4, pp. 523-527.

Owen, D. (1992a), "The implications of current trends in green awareness for the accounting function: an introductory analysis", in Owen, D. (Ed.) Green Reporting: Accountancy and the Challenge of the Nineties, Chapman \& Hall, London, pp. 3-27.

Owen, D. (Ed.) (1992b), Green Reporting: Accountancy and the Challenge of the Nineties, Chapman \& Hall, London.

Owen, D. and O'Dwyer, B. (2008), "Corporate social responsibility: the reporting and assurance dimension", in: Crane, A., McWilliams, A., Matten, D. Moon, J. and Siegel, D. S. (eds), The Oxford Handbook of Social Responsibility, Oxford: Oxford University Press, pp. 384-409.

Owen, D.L., Swift, T.A., Humphrey, C. and Bowerman, M. (2000), "The new social audits: accountability, managerial capture or the agenda of social champions", The European Accounting Review, Vol. 9, pp. 81-90. 
Phillips, M. (2015), "Re-ethicizing corporate greening? Ecofeminism, activism and the ethics of care", in Pullen, A. and Rhodes, C. (Eds) The Routledge Companion to Ethics, Politics and Organizations, Routledge, London.

Phillips, M. (2017), “'Daring to care': challenging corporate environmentalism”, Journal of Business Ethics.

Plumwood, V. (1993), Feminism and the Mastery of Nature, London: Routledge.

Plumwood, V. (2002), Environmental Culture: The Ecological Crisis of Reason, Routledge, New York.

Prokhovnik, R. (1999), Rational Woman: A Feminist Critique of Dichotomy, Routlesge, London.

Radford Ruether, R. (2005), Integrating Ecofeminism, Globalization, and World Religions, Rowman \& Littlefield Publishers, New York.

Romstötter, J. (2015), Das vergessene Wunder: Wie wir aus der Nature Kraft, Erfolg und Inspiration schöpfen können, Berlin: Goldegg.

Saravanamuthu, K. and Lehman, C. (2013), "Enhancing stakeholder intraction through environmental risk accounts", Critical Perspectives on Accounting, Vol. 24, pp. 410-437.

Sessions, R. (1991), "Deep ecology versus ecofeminism: healthy differences or incompatible philosophies?", Hypatia, Vol. 6, No. 1, pp. 90-107.

Sevänen, E. (2004), "The study of cultural identity: development and background of a multi-disciplinary field of research", In: Kupiainen, J., Sevänen, E. and Stotesbury, J. A. (Eds) (2004), Cultural Identity in Transition: Contemporary Conditions, Practices and Politics of a Global Phenomenon, New Delhi: Atlantic, pp. 33-63.

Shiva, V. (1989), Staying Alive: Women, Ecology and Development, Zed Books, London.

Slicer, D. (1995), "Is there a feminism - deep ecology debate?", Environmental Ethics, Vol. 17, Summer, pp. 151-169.

Spence, C. (2007), "Social and environmental reporting and hegemonic discourse", Accounting, Auditing an Accountability Journal, Vol. 20, No. 6, pp. 855-882.

Spence, C. (2009), "Social Accounting's emancipatory potential: A Gramscian critique", Critical Perspectives on Accounting, Vol. 20, pp. 205-227.

Stevenson, L. A., Ferguson, J. and Power, D. M. (2014), "The use of teaching resources in accounting education", in: Wilson, R. M. S. (ed.), The Routledge Companion to Accounting Education, Routledge, London, pp. 420-445.

Swift, T. A. (2001), "Trust, reputation and corporate accountability to stakeholders", Business Ethics: A European Review, Vol. 10, pp. 16-26.

Tassoni, J. P. (1998), "Deep response: an ecofeminist dialogical approach to introductory literature classrooms", in Gaard, G. and Murphy, P. D. (Eds), Ecofeminist Literary 
Criticism: Theory, Interpretation, Pedagogy, Urbana and Chicage: University of Illinois Press, pp. 204-223.

Thomson, I., Dey, C. and Russell, S. (2015), “Activism, arenas and accounts in conflict over tobacco control", Accounting, Auditing and Accountability Journal, Vol. 28, No. 5, pp. 809-845.

Tinker, T. (1985), Paper Prophets: A Social Critique of Accounting, Holt, Rinehart and Winston, London.

Vieten, U. M. (2011), "Situating contemporary discourses on cosmopolitanism in Britain and Germany: Who is the other, anyway?", In: O'Donovan, P. and Rascaroli, L. (Eds), The Cause of Cosmopolitanism: Dispositions, Models, Transformations, Peter Lang, Oxford and Bern, pp. 89-114.

Wachholz, S. (2011), "Ecofeminism”, in Chatterjee, D.K. (Ed.) Encyclopedia of Global Justice, A-I, Volume 1, Springer, New York, pp. 289-290.

Warren, K.J. (Ed.) (1994), Ecological Feminism, Routledge, London.

Warren, K.J. (Ed.) (1997), Ecofeminism: Women, Culture, Nature, Indiana University Press, Bloomington.

Welford, R. (1997), Hijacking Environmentalism: Corporate Responses to Sustainable Development, Earthscan, London.

\section{CSR Reports:}

BP (2014), Sustainability Report, available at: http://www.bp.com/en/global/corporate/sustainability.html?gclid=CL34zO7itMYCFQXn wgodUWQFLg (accessed, 15 June 2015).

Rio Tinto (2015), Sustainable Development Report, available at: http://www.riotinto.com/our-commitment-107.aspx (accessed, 2 December 2016).

McCormick (2015), Corporate Social Responsibility Report, available at: http://www.mccormickcorporation.com/public/CORP/files/McCormick_CSR_Report_201 5.pdf (accessed, 2 December 2016).

Ford (2016), Sustainability Report 2015/16, available at: http://corporate.ford.com/microsites/sustainability-report-2015-16/index.html (accessed, 2 December 2016).

Shell (2015), Sustainability Report, available at: http://reports.shell.com/sustainabilityreport/2015/servicepages/download-centre.html (accessed, 2 December 2016). 